\title{
Empowering Business Process Improvement of Kue Basah Ny. Anong in Cianjur, West Java
}

\author{
Cynthia Yuni Luis ${ }^{1 *}$, Winston Purnama ${ }^{2}$, Hans Nicholas ${ }^{3}$, \\ Vincent Jonathan ${ }^{4}$, Arvin Victor Maruli ${ }^{5}$, Abbytha Zweima AR Wartono ${ }^{6}$, \\ Albert Hasudungan ${ }^{7}$ \\ ${ }^{1}$ Business Mathematics Major. Prasetiya Mulya University \\ ${ }^{2}$ Business Major, Prasetiya Mulya University \\ ${ }^{3}$ Branding Major, Prasetiya Mulya University \\ ${ }^{4}$ Accounting Major, Prasetiya Mulya University \\ ${ }^{56}$ Business Major, Prasetiya Mulya University \\ ${ }^{7}$ Business Economics Major, Prasetiya Mulya University \\ Author E-mail: cynthia.luis@student.pmsbe.ac.id
}

\begin{abstract}
A B S T R A K
UMKM di Indonesia telah memberikan kontribusi yang sangat signifikan dan menjadi penopang perekonomian Indonesia. Pada program pendampingan komunitas UMKM di Cianjur, komunitas menunjukkan minat yang besar untuk mengembangkan usaha kecil. Dalam studi ini, yang diangkat adalah kasus Kue Basah Ny Anong, yang merupakan merk dagang dari bisnis UMKM ini. Kendala UMKM Indonesia adalah proses bisnis yang tidak efisien dan tidak efektif seperti yang ditemui pada bisnis Kue Basah Ny Anong. Program pendampingan ini ditujukan untuk: Pertama, meningkatkan proses bisnis yang mencakup masalah operasional, terutama meningkatkan tingkat keamanan dan hygienitas serta standarisasi makanan. Kedua Untuk masalah keuangan, program ini memberikan pelatihan dan pendampingan untuk mengembangkan system pencatatan bookkeeping untuk memonitor perkembangan bisnis. Dalam aspek pemasaran, juga dibantu untuk mengembangkan promosi dan penjualan melalui berbagai media online. Untuk bidang Sumber Daya Manusia, pelatihan diberikan kepada anggota usaha dan keluarga Ny Anong untuk meingkatkan potensi bisnis. Program intervensi dan pendampingan ini dilakukan selama enam bulan dari Januari sampai Juni 2020.
\end{abstract}

Kata Kunci: UMKM, Kue Tradisional, Pemasaran dari Mulut ke Mulut, Standarisasi Makanan, Kesehatan Makanan, Proses Bisnis.

\section{A B S T R A C T}

SMEs in Indonesia has given a significant monetary contribution to the Indonesian economy. In our Community Development case study in Cianjur, some of the community members showed enthusiasm in SME business. In this study, the case was observed through Kue Basah Ny. Anong, which was the business' brand name. In Indonesia itself, the obstacles of SME businesses were inefficient and ineffective business processes to enhance their business growth. These drawbacks were also found in Kue Basah Ny. Anong. These Community Development activities were held to improve their business process 
on operational, financial, marketing, and human resource aspects. Firstly, in the operational aspect, the activities were to improve food hygiene and standardization. Secondly, in the financial aspect, this Community Development project provided training and facilitation to make daily financial bookkeeping to monitor their business progress. In the marketing aspect, the assistance was to find other alternative marketing strategies to expand marketing through social media and WhatsApp. This tool was considered effective as the consumers in Cianjur possessed mobile phones. In the human resource aspect, training was provided to Mrs. Anong's family members to promote their business and products to potential business partners and consumers. From the Community Development intervention, the impact was a better business model canvas and approach toward their customers and partners within six months of this Community Development project (one semester). The period of this Community Development project was from January to June 2020.

Key word: SME, Traditional cake delicacies, Word of mouth marketing, Standardized food process and hygiene, Business process.

Copyright (C) 2020 Authors. This is an open access article distributed under the Creative Commons Attribution License, which permits unrestricted use, distribution, and reproduction in any medium, provided the original work is properly cited.

\section{INTRODUCTION}

A vast economic growth has been the goal of many developing countries around the world including Indonesia. For the last few decades micro, small, and medium enterprises (SMEs) play an essential role in the development of the Indonesian economy. According to Indonesian official statistics, SMEs make up $99.9 \%$ of the existing business unit in Indonesia that accounts for the employment of $97 \%$ of the workforce and $57,9 \%$ of the Indonesian GDP. These numbers show the importance of SMEs for the future of Indonesia's economic growth. According to the Indonesian constitution law No. 20 of 2008 regarding the definition of micro and medium enterprises, SMEs refer to an enterprise with assets no more than $\mathrm{Rp} 10$ Billion, and they possess annual revenue not exceeding $\mathrm{Rp} 50$ Billion. This constitution explains why the majority of enterprises in Indonesia are classified as micro, small and medium enterprises.

Amidst the vast monetary contribution of SMEs, recent business management research showed some bottlenecks related to business process and other various marketing access to face by some SMEs businesses. In the observation of Rosianti et al. (2017), some small businesses in Indonesia were in slow business progress due to their stagnance to ensure the efficacy of their operational business strategy and limited marketing access they can penetrate to sell their product and services. Furthermore, inefficient customer service and marketing displays were the obstacles to boost their business sales growth of some small and medium businesses in Indonesia (Deloitte, 2015).

To overcome those problems, the Central Government has explicitly stated that one of their means is to improve and promote the growth of these SMEs by improving access to capital and revising policy to ensure lower interest payment for these SMEs. Indonesian Central Government also believes that the vast number of locally operated SMEs can withstand better against economic crisis as one of the reasons that SMEs development will become the government's main focus for years to come. However, to sustain their operating business, policymakers suggested that these SMEs should be supported by good business planning, smooth operation, and marketing that is entering the era of digitalization to increase their competitiveness and sustainability. As a result, many of these SMEs produced excellent products and services, but they did not have the tools and resources to sell their products. To overcome these problems, Joko Widodo as the 
President of Indonesia also launched an initiative to digitize 100.000 SMEs in 30 cities around Indonesia, the President's vision is to make Indonesia the Digital Energy of Asia. SMEs that participate in this initiative will receive help and guidance from the government in the form of the product photo session, domain, and free id hosting. The SME's products that have been registered then will be marketed on many of the digital platforms such as Tokopedia, Blibli.com, and Elevania, etc.

Achieving business process excellence is one of the main goals of business management. the students and other stakeholders involved in this community development program considered that these SMEs must be introduced to the necessary management skills and knowledge, to increase the competitiveness and sustainability of their business unit.

The purpose of this community development program is:

1. Improvement of business operational efficiency and the product output quality, by standardizing operation and removing operation bottlenecks.

2. Improvement of marketing touchpoint and distribution channel of business, by expanding marketing online and offline marketing channels and increasing the number of business partners.

3. Improvement of financial record keeping, by implementing Indonesian standard accounting methods for SMEs SAK EMKM (Standar Akuntansi Keuangan Entitas Mikro Kecil Menengah).

4. Improvement of human capital, by holding business management flash courses for SME owners.

This program aims to help the business owners grow their SMEs and equip them with the right management skills to achieve excellent business processes. For students, faculties, and other stakeholders, this program is expected to increase the practical knowledge of business management, quality of teaching and learning, and bestow positive social impact for SME owners.

From that point of view, this paper aims to explain what had been done by the community development project team to improve the business process of the Kue Basah Ny. Anong small business and how to improve their business models (from January to June 2020). The business progress of the business was monitored by SWOT analysis and Business Canvas Model.

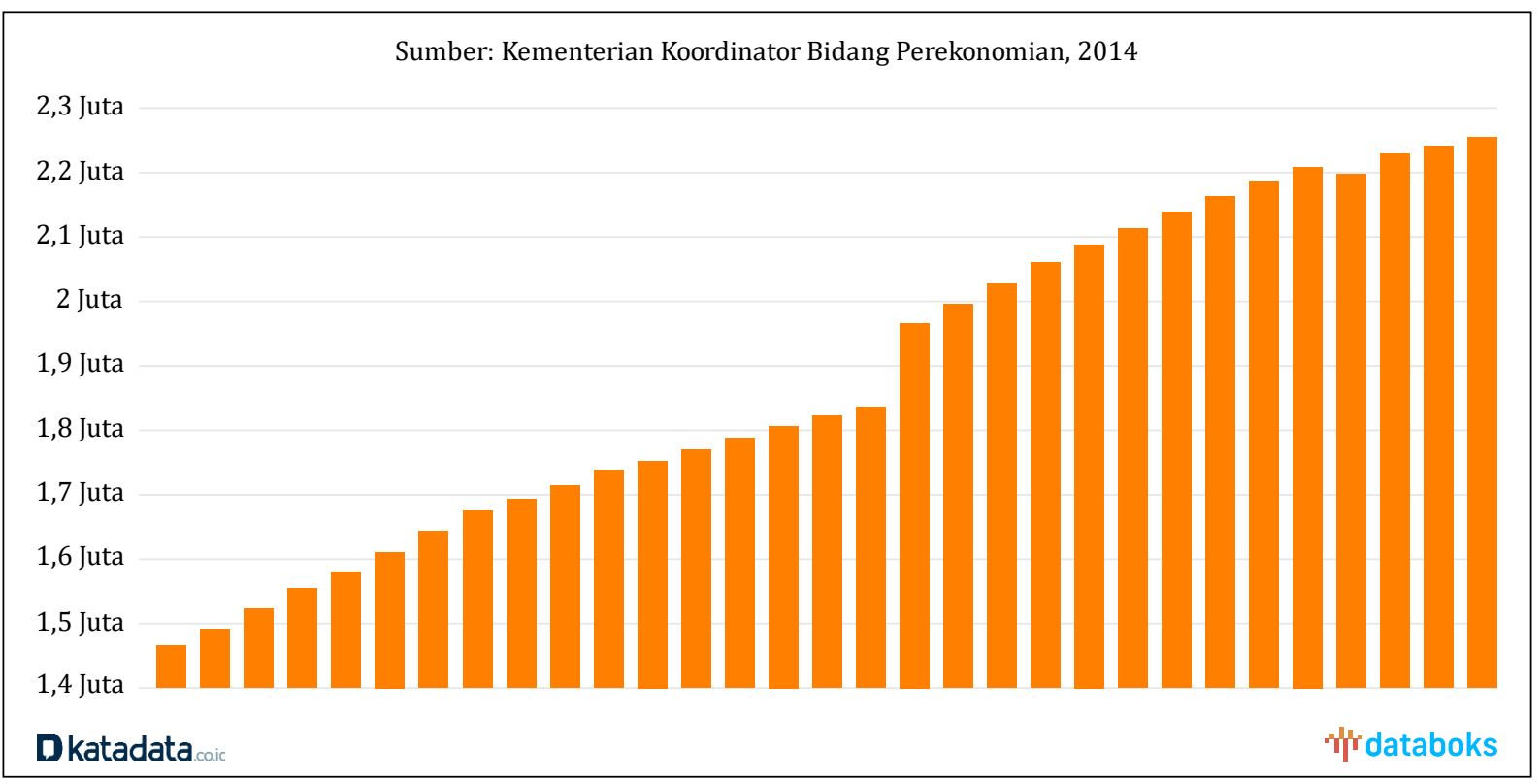

Figure 1. The population of Cianjur Region 
The District of Cianjur where the program was held is located in the West Java region stretched across $3.432 \mathrm{~km}^{2}$ of land area and hosted 2.2 Million citizens. $40 \%$ of the regional gross domestic product came from the agricultural sector which employed nearly $60 \%$ of the workforce in the region, followed by the commerce and service sector which employed $15 \%$ of the workforce. Supported by the statistics the Cianjur Government's main development programs are to support the agriculture and tourism industry in the area to support the economic growth for the region. West Java Region, food consumption consists of around 58\% of household spending which is also essential for the growth of many SMEs that produce food.

Kue Basah Ny. Anong, which is the subject of the Development program, is also one of the microbusinesses that produces and supplies traditional Indonesian cake delicacies to local markets and food vendors. Despite the growth of the local economy, the business has very small sales growth due to the inability to access many distribution channels and marketing touchpoints which larger and more digitalized businesses have the privilege to access. The main aim of Mrs. Anong's business is to provide better marketing touchpoints and distribution channels to many potential customers, improve financial record keeping, and provide managerial skills and technical know-how to grow the business.

Hutahayan (2019) noted that the majority of SME producing Indonesia special food in East Java selects the differentiation strategy. This may also imply that SMEs can set the appropriate strategies for it to strive in different aspects, whether it is creating quality products, formulating a variety of different products, producing products with more benefits than the other products that were sold on the market, and also providing a service that would gain the customers' loyalty. Although this research was focused on the East Java region, this situation may also apply to the West Java Region considering its similar geographical and social features.
In such consignment arrangements, the revenue shares are often selected by the retailer (who then needs to respect the manufacturer's individual rationality) or negotiated (Wang et al., 2001). When the product is perishable (physically or technologically) retailers may not physically return unsold items to the manufacturer, only report to him the volume of sales.

Holt \& Henson (2000) states that there are four aspects of good hygiene practices that are still lacking in SMEs practices, which are:

1. Practical application of legal requirements and industry standards.

2. Specialist advice for specific projects such as refurbishment and HACCP (Hazard Analysis Critical Control Points).

3. Where to obtain reliable service contractors for chemical and pest control and laboratory analysis.

4. Training and course availability for general hygiene and HACCP (Hazard Analysis Critical Control Points).

This proves that most SMEs' awareness regarding the importance of hygiene of their product is still minimum. SMEs performers only have their eyes on how they can earn more profit. But they neglected that maintaining the hygiene of their product is also a plus point and may result in the loyalty of their customers.

It is also vital for food industry practitioners to maintain the hygiene of their kitchen and production space. This is one way to prevent cross-contamination by the food itself. The prevention of cross-contamination by thorough cleaning and sanitizing of surfaces and clothes could improve the general standard of hygiene in the food industry. This would reduce the concentrations of bacteria in the kitchen environment and ensure the production of safe food (Lalla, 2005).

Food packaging is also an important aspect of the food industry. Wang (2013) mentions that the significant effects of visual packaging design on perceived product quality and brand 
preference. Consumers tend to possess a positive attitude towards visual packaging and often evaluate the product and brand positively. This is why food companies should properly design their product packaging to emphasize their brand preference.

Also mentioned by Ahmed et al. (2005), the packaging is an indispensable component of the modern lifestyle. The key trends fostering growth in developed packaged food markets are convenience, functionality, and also indulgence. The real value of packaging is that the package is an integral part of the product today. While corporate functions divide the parts, the consumer does not differentiate between the product, the package, and the equity. They are all seen as one entity that is not separable and completes one another.

According to Nugraha \& Ariyanti (2017), branding plays an important role in a product to differentiate a product from others especially by considering how competitive the society is. Most of the SMEs performers did not realize the importance of branding. They thought that branding is only needed when their business grows from an SME to a large scale business.

People nowadays can not be separated from the use of social media. It has brought a great impact on modern society. It is almost impossible for one to neglect both the power and outcome produced by social media. This has caused a lot of damage to modern society, such as a tool used to commit a crime. But on the other side, we could also use the power of social media to our advantage. It is not common for SMEs performers to use social media as their marketing tool to increase the brand awareness of their product to social media users. It is obvious that the use of social media to enhance marketing is here to stay, so one must consider all possible avenues to positively use it to increase advertising and improve marketing (Hensel \& Deis, 2010).

In this globalization era, there are lots of conveniences offered by e-commerce (Harahap,
2018). This is why youth people prefer online shopping rather than live shopping. This may be a great option to consider for some SMEs who want to broaden their consumer reach. Though, it needs to be noted that this opportunity is only accessible for those with a long-term lifespan. This opportunity is impossible for those SMEs which offer short term lifespan products.

Van Caneghem \& Van Campenhout (2012) states that SMEs are financially constrained because they face difficulties in attracting external debt compared to large firms who can easily do it. The disadvantages related to attracting external debt are beyond management control. SMEs are too small to turn to capital markets, while they tend to face a higher cost of debt because they are considered to be riskier. External parties allow them to have a debt with a high-interest rate considering the high risk that they have. This made SMEs even harder to develop.

In an SME, there are few options regarding human resource management systems. It can help SMEs practitioners to have an effective human resource management system. Here are the option alongside with its benefits and limitations according to Ghassemieh et al. (2005):

\section{A. No change}

Sometimes, to achieve the most, we have to consider no change in our strategy at all. For small businesses with a very small employee base, such as one, two, or even no employees, it is normal that they have no formal human resource support or strategy. Mostly because they do not need one yet. But as the business grows, whether they like it or not, they need to set up a human resource strategy. The biggest liability for a business with no human resource strategy is the possibility of illegal actions being extended, whether it is intentional or unintentional.

\section{B. Staff assume human resource work}

This option is for one employee to take on human resource responsibilities. This is a risky strategy. It is quite rare and impossible to find someone management system and excels at it at the same 
time. But this is an option to consider when the owner can not afford to hire a human resource management specialist.

\section{Hire a human resource manager}

It is quite expensive to hire a full-time human resource professional who owns legit credentials in the business. But as the business grows larger, this is an important move to up-scale the business into a large enterprise. This also counts as a countermeasure for SMEs to avoid having common human resource mistakes.

\section{Hire human resource consultant}

There is a benefit of having a third party who is not directly affiliated with the internal business to handle employee issues. They would not indulge themselves in these internal issues. Though the cost of hiring a human resource consultant is unaffordable for some SMEs who do not have adequate finances.

\section{E. Outsource human resource}

Because the industry is growing rapidly, the types of vendors and their offerings are changing as well. Most outsourcing vendors provide solutions for recruitment, training, payroll, employee benefits, and risk management. The benefits of having an outsource human resource are quite desirable, including the advantage of economies of scale. However, SMEs must beware and research carefully the vendors before having their employees' information handover.

\section{F. Electronic human resource}

Electronic human resource is beneficial because firms can delegate administrative and technical functions to the electronic human resource system. This way SME managers and owners no longer have to be involved in employee benefits selections or payroll tasks with electronic human resource tools. The other benefit of having electronic human resources is that training becomes so much easier to track by using online training functionality. This also allows SMEs owners to monitor their employees' training through online test scores and employee files that are stored on the system. The only limitation argued by some consultants is that electronic human resource use systems that merge the internal and external recruiting environments, which makes it more difficult for employers to limit recruitment and promotion opportunities.

\section{METHODS}

Data collection and information gathering were used for the business process and management problems. These are the methods used to collect data and information that was needed:

\section{A. Qualitative Survey}

A survey is conducted 2 weeks before the development program to determine the existing condition and business model of Mrs. Anong's SME. The business process was also observed in this survey, enabling authors to find the bottlenecks of operation. The survey was provided to Mrs. Anong to ask some sets of questions regarding business constraints and opportunities.

\section{B. Interview}

Several interviews were conducted with Mrs. Anong and the Village Head of Sukatani village. These interviews revealed Mrs. Anong economic capacity, capability, and well-known reputation as a traditional delicacies producer in the region.

\section{Participatory observation}

Agar, 1996 in Elliott \& Jankel-Elliott (2003) noted that participant observation is the essence of the ethnography approach where direct involvement in community life, observing and talking as to learn from their point of view. To observe Mrs. Anong's day-to-day business process, the authors stayed at Mrs. Anong house for 30 days which was also their production house for Kue Basah Ny. Anong's business.

The tool used for the participatory partner's SME is SWOT analysis, the main purpose of using SWOT was to help the authors involved in identifying the business' strengths and weaknesses also finding opportunities and threats that exist within the market specifically in the Cianjur region. SWOT analysis was 
essential in identifying the factors that affect a business (Pinayani, 2014) to determine the right strategy.

Table 1. SWOT Analysis

\begin{tabular}{|c|c|}
\hline Strengths & Weakness \\
\hline $\begin{array}{l}\text { Vast connection to local food } \\
\text { vendors and raw material } \\
\text { supplier }\end{array}$ & $\begin{array}{l}\text { - Limited operational capacity } \\
\text { for producing large } \\
\text { quantities order }\end{array}$ \\
\hline $\begin{array}{l}\text { - Freshly produced } \\
\text { high-quality products }\end{array}$ & - Short product life-span \\
\hline $\begin{array}{l}\text { - Adequate cooking skills } \\
\text { allowing ease of product } \\
\text { development }\end{array}$ & $\begin{array}{l}\text { - Unhygienic production } \\
\text { process } \\
\text { - Limited marketing channels }\end{array}$ \\
\hline Opportunities & Threats \\
\hline $\begin{array}{l}\text { Tourism-related businesses } \\
\text { could be a potential high- } \\
\text { value customer }\end{array}$ & $\begin{array}{l}\text { - Price taker (homogenous } \\
\text { product) }\end{array}$ \\
\hline $\begin{array}{l}\text { - Rising social media usage } \\
\text { and internet penetration in } \\
\text { Indonesia rural areas } \\
\text { allowing additional } \\
\text { marketing channels }\end{array}$ & $\begin{array}{l}\text { - Low barrier to entry the } \\
\text { business }\end{array}$ \\
\hline
\end{tabular}

As shown by the SWOT analysis one of the strengths that the business possesses was the vast knowledge of locally operated vendors and suppliers that can help distribute the product and acquire cheaper raw materials. Mrs. Anong as the owner of the business also has adequate cooking skills and knowledge that allows for a new product to be developed easily to fulfill the market demand. The business also produced the food daily ensuring the food quality when consumed. However, the short product life-span was limiting product distribution range and consignment. Mrs. Anong also was constrained with a limited production capacity and faced difficulties fulfilling orders in large quantities due to traditional methods that are still being used in the production process and also making the production process unhygienic. The limited knowledge business management strategy, especially in marketing limiting marketing to a very traditional which, was a word of mouth marketing.

The business also posed several opportunities due to the development of tourism that was one of the main focuses of Cianjur's Government, allowing for SME to thrive by creating partnerships with larger businesses in the area such as hotels, restaurants, rest areas, and other tourist attractions. These businesses will create the demand for snacks and the traditional cake delicacies that Mrs. Anong's business produced in a large quantity ( $>300 \mathrm{pcs}$ ) which fell into the category of a high-value customer for Mrs. Anong. Rising social media usage such as WhatsApp for Mrs. Anong was also one of the opportunities creating an accessible and cheap marketing channel for SMEs in rural areas. On the other hand, the products that were produced by Mrs. Anong fell in the category of homogenous product and was a price taker from the market other SMEs in the region also produced similar products with little product differentiation that can be added as a value making the selling price limited to around $\mathrm{Rp} 1500$ for each piece. The business was characterized by a low barrier to entry allowing new SMEs to enter the market with ease due to traditional and simple processes in making the products, also inexpensive and widely available equipment.

The SWOT analysis also allows the author to formulate business decisions based on the existing condition to determine future strategies to maximize strengths and opportunities and also overcome any threats and weaknesses. the strategy can be combined into 4 internal and external factors combination as follows:

A. Strengths and Opportunities (S-0): Purpose partnership with tourism-related businesses such as hotels, restaurants, convention centers, and tourist attractions. With adequate cooking skills, experience, and connections to suppliers allowing Ny. Anong business flexibility to fulfill the various traditional cake delicacies demanded by these businesses.

B. Strengths and Threats (S-T): The connection to suppliers allows for payment installment and cheaper raw materials prices. Standardizing the production process and equipment allows the operator to run with less spoilage and fulfill larger quantities of orders from businesses. 
A. Weaknesses and Opportunities (W-0): The popularity of WhatsApp among Indonesian can be a new channel for SME businesses with limited IT resources such as Mrs. Anong to market their products to the local communities.

B. Weaknesses and Threats (W-T): More hygienic production process can give product differentiation and increase customer satisfaction.

\section{RESULT AND DISCUSSION}

The implementation of the strategy took place from the 29th of January to the 27th of February with direct involvement in the business. The involvement of authors took form in 4 major business area:

\section{A. Operation}

From an operational perspective, Kue Basah Ny. Anong runs into a bottleneck. Because of insufficient tools used and uncomfortable place to conduct production activities, so the team assists to overcome operational bottleneck by providing them some equipment such as gas stove, lamp with large wattage to help the production process be more effective, also provide them kitchen tools such as dessert box and tongs to improve standardizing and food hygiene. Some contributory factors of foodborne illness were associated with inappropriate food storing, and the food storage itself (Bean \& Griffin, 1990 in Walker et al., 2003).

\section{B. Financing}

Implementing financial reports regularly and presenting them based on SAK EMKM (Standar Akuntansi Keuangan Entitas Mikro Kecil Menengah) will be very useful for Kue Basah Ny. Anong in running its business. The purpose of financial statements, its significance and value were to facilitate the possibility of multicriteria evaluation of the effectiveness of the performance of companies (Casta and Ramond, 2016). Following this definition, Financial reporting will be used as the basis for making managerial decisions. Financial report data and its analysis served as a tool for identifying problems in managing financial and entities' operations. The results of the current Financial Statement Analysis itself will assist in providing direction in prospective analysis, such as sales or production projections. Then the application of financial statements by an entity will increase the effectiveness and efficiency of management operations and finances.

\section{Marketing}

Previously, Kue Basah Ny. Anong only used two channels in marketing her products. The two channels were door-to-door direct selling and consignment. To extend the marketing channel, the authors approached 15 hotels and villas to add more third-party partners for consignment and cooperative relationships with hotels or villas. As tools for the cooperation offering program, the authors made a brochure that contains a price list and type of products that Mrs. Anong offers. Also, a business name card for Kue Basah Ny. Anong was provided for further marketing use. Shaun Dole (2007) states that word of mouth marketing is still effectively used to influence someone's buying decision process as the most significant factor for someone to decide on buying it from a friend's recommendation. To add more marketing touchpoints, it was suggested that Mrs. Anong to promote her business via WhatsApp as it was one of the most used social media in the area. With these offering programs and adding more marketing touchpoints, authors intended to increase the brand awareness of Kue Basah Ny. Anong's business.

Kue Basah Ny. Anong uses consignment as one of the distribution channels for sales revenue, and the consignment is the most profitable channel that Kue Basah Ny. Anong do for sales. According to Wang et al. (2001), When the product was perishable (physically or technologically), retailers may not physically return unsold items to the manufacturer, they only report to the suppliers the volume of sales, from that Kue Basah Ny. Anong doing the same as the economic theory model of Wang. 


\section{Human Resources}

Kue Basah Ny. Anong was only made by 3 people, Mrs. Anong herself, and both of her daughters, Mrs. Eno and Mrs. Ayu, also her husband, were in in charge of the delivery. The strategy to boost the Human Resources aspect was to train his family to provide standardized work arrangements to produce Kue Basah Ny. Anong to achieve be the best version of the home industry. Hence, the initial step to maintain human resources was to make sure that the worker includes Mrs. Anong were on the same track and the same vision to make the cake. Secondly, it was ensured that the worker and the workload are equal so the work will be done efficiently and effectively.

the interview was made with some local villagers of Sukatani Village himself. From this interview, it can be concluded that Mrs. Anong herself was known as a very influential individual in the area. The village headman also explained that Kue Basah Ny. Anong was a vivid option to consider when someone in the region planned a gathering with snacks needed. Aside from its affordable price, they offered a great variety of choices for the customer to choose from. This allowed the customers to balance the taste of sweet and savory among the snacks that they offered. The skill of Mrs. Anong is also a trump card in her business. Being in the food industry as a cook for many years helped her to gain extraordinary cooking skills. The customers are welcomed to request a new variety of product that is not offered by Kue Basah Ny. Anong. In this case, Mrs Anong was very flexible about it and manages to fulfill the customer's expectations every single time.

To strengthen Kue Basah Ny. Anong marketing touchpoints, branding was an essential thing to do. Hence, a name card and brochure were made to enhance this particular point. The name card and brochure was used as a marketing tool to spread brand awareness of Kue Basah Ny. Anong.

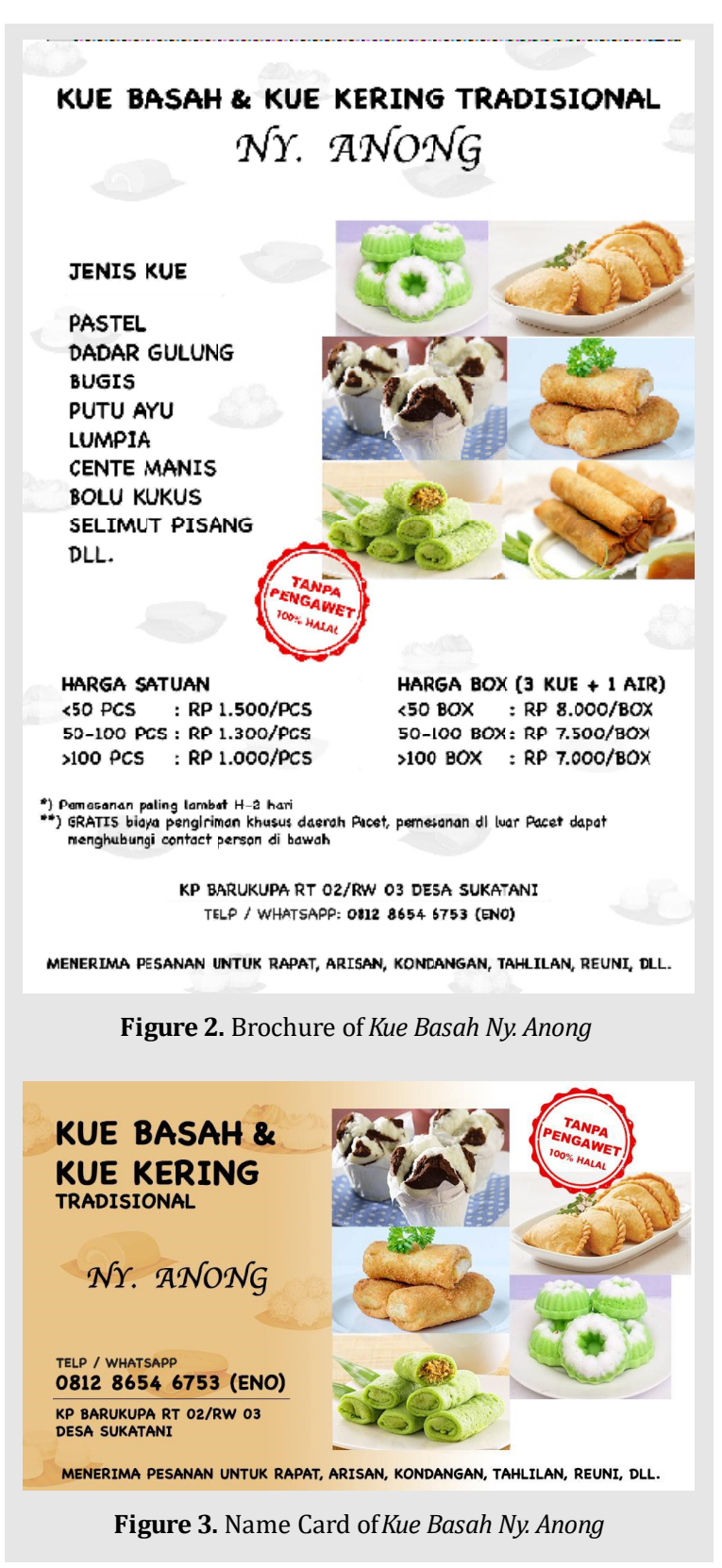

By assisting the business process of Mrs. Anong, it was expected that the improvement of her business model canvas was attained. Before initiating business process improvement, the business has three main partners which were packaging supplier, raw material supplier, and consignment point with a food vendor located at a nearby traditional market. Key activities for the business included production, door-todoor sales, and delivery to food vendors. While the resource required to run the business was raw materials such as flour, food coloring and flavoring, baking powder, and other ingredients, 


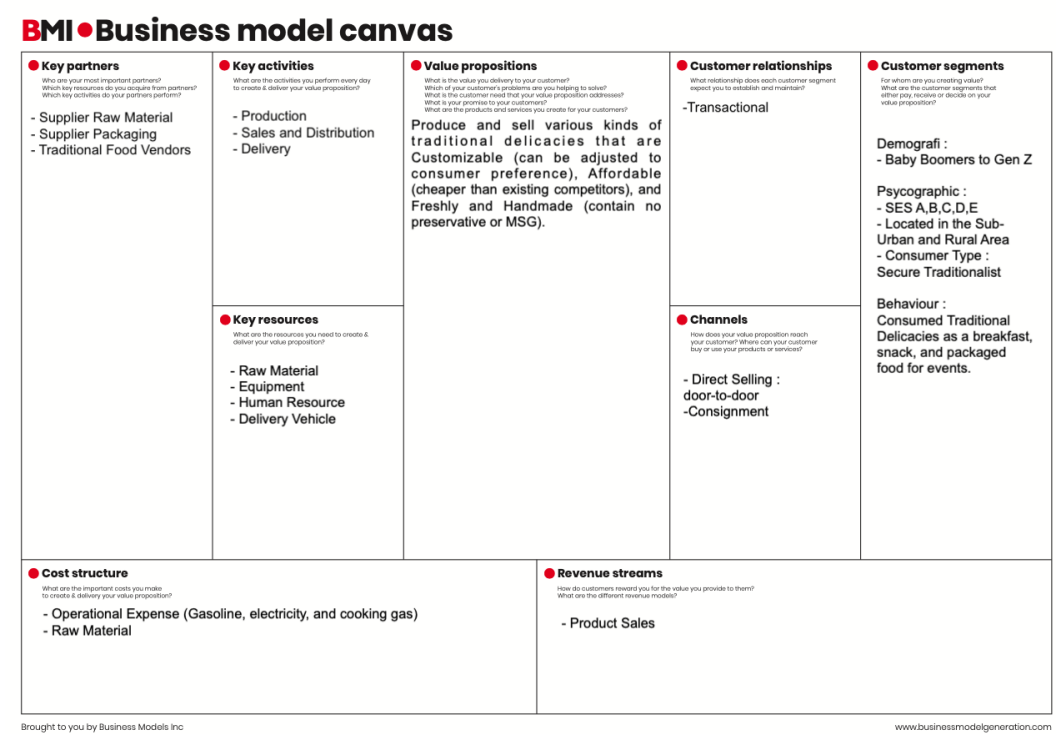

Figure 4. BMC of Kue Basah Ny. Anong prior to the development program

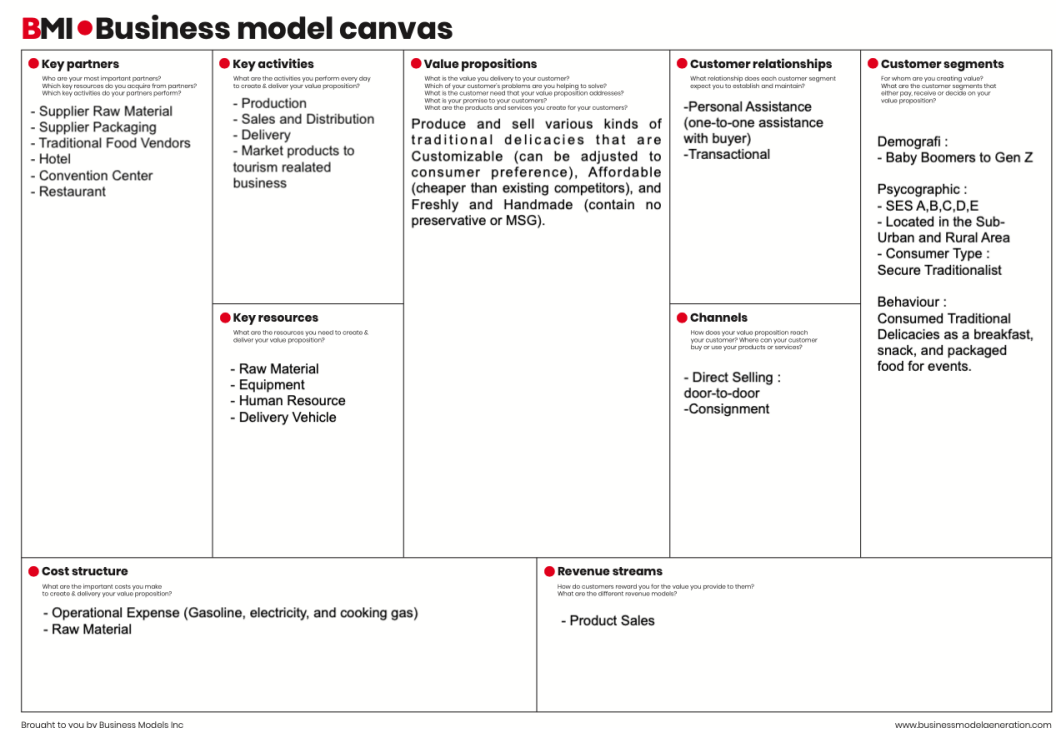

Figure 5. BMC of Kue Basah Ny. Anong after the development program

the business also required production equipment, adequate human resources, and delivery vehicles. The cost structure of the business consists of operational expenses and raw materials expenses. The customer relationship was managed only transactionally, retention of customers is one of the business weaknesses of Kue Basah Ny. Anong. The customer segment consists of people across all generations and social classes who are located in the Cianjur region and like traditional snack delicacies. The business itself sells products through consignment and also door-to-door sales, and product sales were the only revenue stream for their small business.
After the improvement, there was an expansion of marketing and distribution channels; the authors added partnerships to several locally operated hotels and food vendors in the traditional market. By implementing a partnership strategy with local businesses, Mrs. Anong also has longterm business relationships, instead of just transactional relationships with customers. The hygienic production process was also an improvement due to a standard operating procedure and new packaging equipment such as sealer, which could improve product quality and customer satisfaction. 


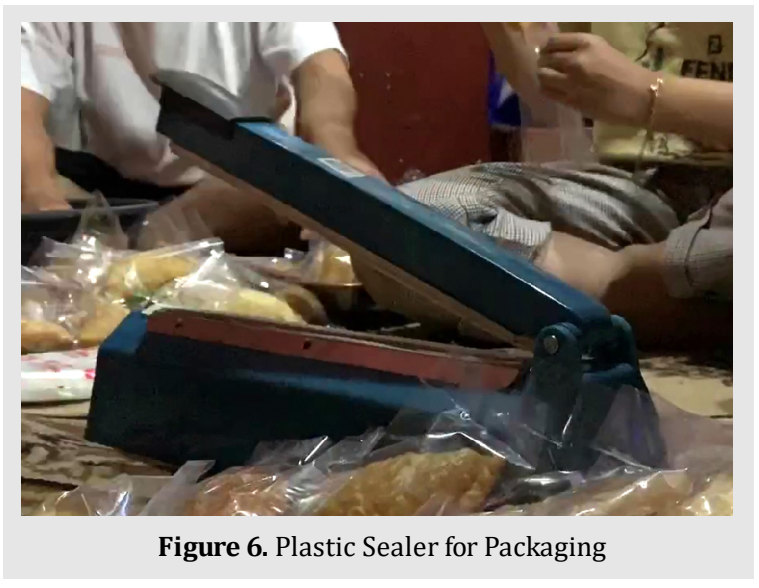

\section{CONCLUSION AND RECOMMENDATION Conclusion}

Kue Basah Ny. Anong is an SME that has already been established for 19 years. This particular SME specialized in producing traditional cake delicacies. Even though it has been operating for a long time for this specific business area, Mrs. Anong still needs some improvement in some aspects, especially the operation and marketing sectors.

After being directly involved in the day to day and observing the business process of Kue Basah $N y$. Anong, there are few conclusions which were divided into their sectors:

\section{A. Operation}

Regarding the operation sector, the authors identified a bottleneck in Mrs. Anong's business. Therefore, production equipment was provided to improve the production process of Kue Basah Ny. Anong business itself. Within this improvement, the authors aim for the effectiveness of the production process and improving the hygiene of Mrs. Anong's products. The addition of a stove helps to increase the production effectiveness, while the addition of a plastic sealer helps Kue Basah Ny. Anong to improve its packaging and hygiene at the same time.

\section{B. Marketing}

Selling door-to-door is still considered an effective marketing strategy for Mrs. Anong to sell her products. Using WhatsApp to spread awareness around the area is one of the strategies that Mrs. Anong implements. Authors are also involved in adding more cooperative relationships with some hotels and or villas, and consignment programs as well in schools to broaden the brand awareness of Kue Basah Ny. Anong business.

Traditional cake delicacies like Mrs. Anong's product has a short product lifespan, which can only last for 3 days in good condition. This implicates Mrs. Anong's products cannot be sold through an online channel or marketplace because the delivery process may consume some time. This is why authors avoid online channels in marketing and selling Mrs. Anong's products.

\section{Financing}

Financial reporting will be used in making strategic decisions for Kue Basah Ny. Anong. By analyzing financial statements can show the current entity's performance (profitability) and provide direction in prospective analysis to improve sales also operational effectiveness and efficiency.

\section{Human Resource}

As for the human resource sector, in the production process, Mrs. Anong was helped by her two daughters and other relatives. This helps her to minimize the cost of production. It resulted in having more profit in the business. This circumstance also eliminates the risk of having internal issues within employees. Training them to use WhatsApp as a marketing strategy indirectly helped them to improve their skills.

\section{Recommendation}

Authors' recommendations for Kue Basah $N y$. Anong business is as follows:

1. In providing traditional cake delicacies, standardized food hygiene is essential especially in storing foods and packaging. Therefore, Mrs. Anong needs to maintain and ensure that all of the equipment is in good condition and appropriate for food storing and applying the standardized process as well to keep the effectiveness and hygiene 
Cynthia Yuni Luis, et al. / Empowering Business Process Improvement of Kue Basah Ny. Anong in Cianjur,

of the product.

2. Word of mouth marketing is still considered an effective way to sell Mrs. Anong's product, hence authors suggest Mrs. Anong spread brand awareness of Kue Basah Ny. Anong business using WhatsApp. Also, broaden the marketing channel through consignments and cooperative relationships with hotels and or villas for extending more revenue streams.

3. An entity must record financial statements regularly to find out real-time operational performance and identify if there is a diminished performance.

4. To maintain production quality, Mrs. Anong needs to train her daughters and other relatives to keep the production process standardized. This leads to maintaining the taste of the Kue Basah Ny. Anong's products itself.

\section{ACKNOWLEDGEMENT}

The authors would like to thank Mrs. Anong and her family for the warm welcome, help and support during the Community Development period. Thank you, Eiliane Angela and Gagas Hakiki as the facilitator that guides throughout the Community Development period. The authors would also like to thank Pusat Pengembangan Usaha Kecil (PPUK) of Prasetiya Mulya University for taking part in the Community Development. Last but not least, thank you Desk of Comdev 2020 for preparing and providing all the necessary preparation before and during the Community Development period.

\section{DAFTAR PUSTAKA}

Ahmed, A., Ahmed, N. and Salman, A. (2005). Critical issues in packaged food business, British Food Journal, 107(10), 760-780.

Delloite, 2015, “UKM pemicu kemajuan Indonesia:instrumen pertumbuhan nusantara”, Laporan Penelitian Bisnis <https://www2.deloitte.com/content/dam/Deloitte/id/Documents/finance/id-fas-smepowering-indonesia-success-report-bahasa-noexp.pdf

Doyle, S. (2007). The role of social networks in marketing. Journal of Database Marketing \& Customer Strategy Management, 15(1), 60-64.

Elliott, R., \& Jankel-Elliott, N. (2003). Using ethnography in strategic consumer research. Qualitative market research: An international journal.

Ghassemieh, G., Thach, L. \& Gilinsky, A. (2005). Does my business need a human resources function? a decision-making model for small and medium-sized firms, New England Journal of Entrepreneurship, 8(2), 25-36.

Harahap, D. A. (2018). Perilaku Belanja Online di Indonesia: Studi Kasus. JRMSI-Jurnal Riset Manajemen Sains Indonesia, 9(2), 193-213.

Hutahayan, B. (2019). Factors affecting the performance of Indonesian special food SMEs in entrepreneurial orientation in East Java, Asia Pacific Journal of Innovation and Entrepreneurship, 13(2), 231-246.

Hensel, K., \& Deis, M. H. (2010). Using social media to increase advertising and improve marketing. The Entrepreneurial Executive, 15, 87.

Holt, G. \& Henson, S.J. (2000). Information for good hygiene practice in small businesses, British Food Journal, 102(4), 320-337.

KOMINFO, P., 2020. UMKM Go Online, Upaya Wujudkan Visi “Digital Energy Of Asia”. [online] Website Resmi Kementerian Komunikasi dan Informatika RI. Available at: <https://www.kominfo.go.id/content/ detail/9514/umkm-go-online-upaya-wujudkan-visi-digital-energy-of-asia/0/berita_satker> [Accessed 20 June 2020]. 
Lalla, F., Dingle, P., \& Cheong, C. (2005). The Antibacterial Action of Cloths and Sanitizers and the Use of Environmental Alternatives in Food Industries. Journal of Environmental Health, 68(5), 31-35. Nugraha, H. S., \& Ariyanti, F. (2017). Penerapan Branding Pada UKM Makanan Ringan di Kabupaten Jepara. Jurnal Administrasi Bisnis, 6(1), 16-23.

Pinayani, A. (2014). Peningkatan Mutu Pendidikan dan Pengajaran Pada Program Pendidikan Ekonomi dan Koperasi Melalui Pengembangan Model Pembelajaran Ekonomi. Jurnal Pendidikan Ekonomi dan Koperasi, 9(1).

Rosianti, NC, Mahendrawathi, ER, Nisafani, AS (2017), Analisis Tingkat Kematangan Proses Bisnis dan Kesiapan Teknologi Informasi Studi Perusahaan Garmen Mikro, Kecil, dan Menengah di Jawa Timur, Jurnal Teknik ITS, Vol.6, No.2.

Sukoyo, Y., 2020. Jokowi Berperan Besar Dorong Peningkatan UMKM. [online] beritasatu.com. Available at: $<$ https://www.beritasatu.com/nasional/543278-jokowi-berperan-besar-dorong-peningkatanumkm> [Accessed 18 June 2020].

S.T. Wang, E. (2013), The influence of visual packaging design on perceived food product quality, value, and brand preference, International Journal of Retail \& Distribution Management, 41(10), 805-816.

Van Caneghem, T., \& Van Campenhout, G. (2012). Quantity and quality of information and SME financial structure. Small Business Economics, 39(2), 341-358.

Walker, E., Pritchard, C., \& Forsythe, S. (2003). Food handlers' hygiene knowledge in small food businesses. Food control, 14(5), 339-343. 